\title{
Assessment of Electricity Sector Using Geomatics Techniques: (Ramadi City as a Case Study)
}

\author{
Hisham M. Jawad Al Sharaa \\ Civil Engineering Dept., University of Technology-Iraq, Alsina'a street,10066 Baghdad, Iraq. \\ Corresponding author Email: 40316@uotechnology.edu.iq
}

\section{H I G H L I G H T S}

- GIS can manage data on electricity distribution with data identifying attributes.

- Estimate electrical demand throughout which have major problems in 750 to 770 MW.

- Interactive map with databases that can be used to create maps to analyzes.

- The digital interface allows for timely, accurate, and easy information.

- Important for making quick and effective decisions.

\section{A R T I C L E I N F O}

Handling editor: Wasan I. Khalil

Keywords:

Geomatics techniques

Assessment

Electricity Sector
A B S T R A C T

\begin{abstract}
Geomatics involves the collection, management, integration, representation, analysis, modeling and display of geographically referenced information describing both the Earth's physical features and the built environment. One of the main use of this tool is to estimate electrical energy demand throughout Al Anbar Governorate, which have major problems in this sector with about 750 to $770 \mathrm{MW}$. The consumption of the city of Al Ramadi is about $200 \mathrm{MW}$. According to official forecasts by the Directorate of Electricity Networks of Al Anbar, this demand is expected to increase to about $900 \mathrm{MW}$ during the summer of 2020. The present distribution systems in Al Ramadi are mostly overhead. Gradual conversion from overhead to underground systems, particularly at the $11 \mathrm{kV}$ level, is recommended, especially in the central part of the city. This will allow for higher system safety and reliability, and for a much aesthetically improved appearance. This necessitated the construction of additional backup stations. Furthermore, prepared a plan for stations that have been constructed in the year 2020, in order to meet the anticipated demand growth during the planning period. Long-term plan for the Governorate of Al Anbar in order to cope with the increased demand for electrical energy.
\end{abstract}

\section{Introduction}

In the past 20 years, GIS has developed rapidly, increasing its potential for effective use in both public and private organizations. [1] However, developments of the effective enterprise use of GIS and the creation of a national infrastructure supporting its use have been slow. GIS provides the platform for the development of place-based data systems for measuring the effect of federally supported housing programs and supporting housing policy decision-making. [2] [3] Up-to-date, accurate information is needed to analyze issues and trends, examine the effect of the programs, and support nationwide analysis. This work provides some elaboration on the requirements that are essential for the future development of the generation, transmission and distribution sub-sector in accordance with the development of the city. The data and information were collected from the directorate of electricity of al Anbar governorate, directorate of electricity of the upper Euphrates, directorate of distributing electricity, and ministry of electricity and field visits. [4] The provided information contained the key elements of the power distribution network, including production, transport, transfer, and distribution stations and their capabilities, as well as transmission lines, sub-main lines, and distribution cables. The main components of the electrical sector in Al Ramadi, current status and the future plans for developing the sector were Assessments presented in previous work [5].

\section{Study Area}

The City of Al Ramadi is the capital of Al Anbar Governorate and is located at the intersection of the Euphrates River and Al Warrar Channel, at $110 \mathrm{Km}$ to the west of Baghdad and about $450 \mathrm{Km}$ from the Iraq-Jordan border along the Baghdad Rutba - Damascus highway. [6] 


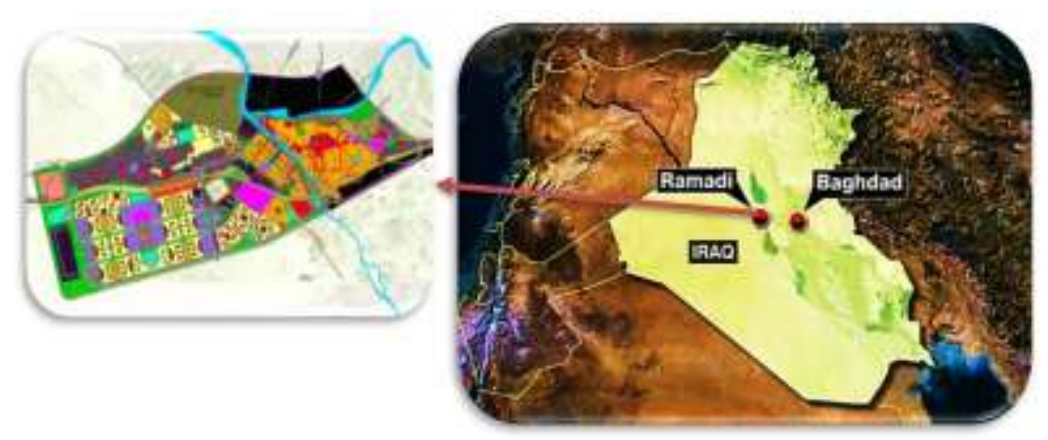

Figure 1: Ramadi city

The population of Al Ramadi has grown from just under 10,000 in 1947 to about 30,000 in 1965. The City's population was estimated at about 39,000 in 1970 and its present population is estimated to grow to approximately 235,500 . Relatively gentle slopes generally characterize the topography of Al Ramadi. The town center is built on flat drained land situated between dykes to the north and south. A high-water table prevails under most of the City area as shown in the figure below.

\section{Assessment of Electricity Sector}

\subsection{Production}

The existing production station in Al Anbar Governorate is the Sad Al-Haditha hydroelectric station, which supplies almost $400 \mathrm{KV}$ to the two stations of Al-Qa'em and Baghdad West, and from them, it is distributed to other main stations of high voltage $(132 \mathrm{KV})$, and then further distributed to secondary stations. [7] Figure 2 shows the distribution scheme of the electricity network and secondary stations in Al Anbar Governorate. There are also two backup stations in the City, which are Al-Rabee Station; with a capacity of (3X1250 KVA), located in the Altheleh region, and currently used to feed Al Ramadi General Hospital in cases of emergencies or disruptions in the main electrical network. The second station is Tameem Station; with a capacity of ( 8 X1750 KVA) and is used as a backup station at peak times.

Based on the available information from the Directorate of Electricity Networks of Al Anbar, the electrical power requirements of $\mathrm{Al}$ Anbar Governorate are estimated at $760 \mathrm{MW}$, while the average electrical power generated from the main electrical power generating station, at Sad Al-Haditha does not exceed $700 \mathrm{MW}$ in the best times. As in the other cities of Iraq, there are substantial numbers of domestic diesel-fueled generators and invested by the private sector, which is providing subscribers (especially in the residential sector) with electricity during limited hours, in order to meet their needs when a break-in basic sources of energy occurs.

\subsection{Transmission}

In addition to the electrical power generated at Sad Al-Haditha Station, Al Anbar Governorate receives electricity through $132 \mathrm{KV}$ high tension electrical transmission lines from the Baghdad Governorate, as shown in Figure 2 These high-tension transmission lines feed the main switching stations north of Fallujah power is consumed and the Fallujah Cement Facility. However, these lines are currently non-functional, as most of the Baghdad-generated electrical by Baghdad, and no surplus is available for Al Anbar.

There are nineteen main distribution stations of electricity with (132/33/11 KV) in Al Anbar Governorate[8], as shown in Figure 2, but all are old and require rehabilitation or replacement by new sub-stations. The stations are as follows: AL-Ratbah, Al-Qa'em, Anna, Hit, Fallujah, Fallujah Cement, Crushers of Al-Motanaqela, Akashat Alwasatieh, Akashat Al-qadeema, AlWasatieh, Alnahieh, Al-Roosieh, Haditha, Al-Baghdadi, Kbeisa, Warrar (Al-Ramadi national), Sufieh (east of Ramadi), Habbaniyah, Khan Dhari. Two of the nineteen main distribution stations are located in Ramadi, and they are Warrar Station (Ramadi national) with a capacity of $70 \mathrm{MW}$. The second is Sufieh Station (east of Ramadi) with a capacity of $30 \mathrm{MW}$.

The electrical loads that are distributed by the two stations of Al Ramadi are not sufficient and do not meet the actual needs of the City, which results in serious shortages in the region. Therefore, it proposed to establish another two main distribution station to meet the urgent needs in the electricity sector. These two stations are the Station of South Ramadi and the Station of West Ramadi.

Table 1: Electricity Stations in the city of Ramadi [6]

\begin{tabular}{ccc}
\hline Name of the Sub-Station (33 KV) & Source of Electricity (132 KV) & Power (MW) \\
\hline Qadisiyah & Warrar (Ramadi National) & 28 \\
Hussein / north of Ramadi & Warrar (Ramadi National) & -- \\
Al-Zujaj & Warrar (Ramadi National) & 10 \\
Al-malahma & Sufieh (Ramadi East) & 30 \\
Khaldiya & Sufieh (Ramadi East) \\
\hline
\end{tabular}




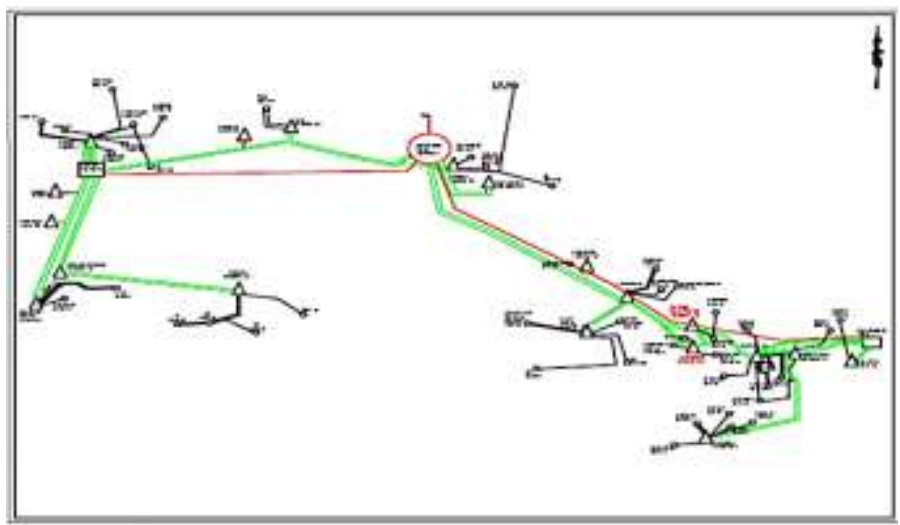

Figure 2: Map of Electric Distribution Network Stations in Al Anbar Governorate

\subsection{Distribution}

Distribution is done through a number of electricity sub-stations of $(33 / 11 \mathrm{KV})$ that are fed from main stations of $(132 / 33 / 11 \mathrm{KV})$. [7] Table 1 shows the name/location station and the source of electricity and power of each sub-station.

\section{Assessment of Existing Network}

Figure 3, and tables 2, 3, 4 demonstrate the existing distribution network of electricity, as they show the main station's name, sub-stations, the length of utilized lines in the distribution network and the number of transformers in the sub-station.

\subsection{Demand}

The estimated electrical energy demand throughout Al Anbar Governorate is about 750 to 770 MW. The consumption of the city of Al Ramadi is about $200 \mathrm{MW}$. According to official forecasts by the Directorate of Electricity Networks of Al Anbar, this demand is expected to increase to about $900 \mathrm{MW}$ during the summer of 2020. [9]

As a result of the current situation in Iraq, and the inability of electricity networks to meet the demand for electrical power, most of the factories in the Governorate of Al Anbar, such as cement factories, glass, ceramics, phosphates, and other industries are either inoperative, suspended production or significantly decreased their productivity rates. This indicates that most of the current consumption is domestic and part of it is commercial. The consumers in the City of Al Ramadi can be classified, as reported by local officials, as shown in Table 5 below.

Table 2: Length of existing distribution network with the main and sub-stations and the number of transformers [6]

\begin{tabular}{|c|c|c|c|}
\hline Station Name & Feeder & Voltage KV & Length (km) \\
\hline \multirow{13}{*}{$\begin{array}{l}\text { North Al Ramadi } \\
\text { (Al Husain) } \\
33 \mathrm{KV}\end{array}$} & AL Warrar & 11 & 3.5 \\
\hline & Al-Ezazyeh & 11 & 3 \\
\hline & Al- Sena'a & 11 & 6 \\
\hline & Al Jam'yeh & 11 & 2.5 \\
\hline & AL Qataneh & 11 & 3 \\
\hline & Al Theleh & 11 & 2.5 \\
\hline & Spare & 11 & -- \\
\hline & 20 Street & 11 & 7 \\
\hline & Ramadi General Hospital & 11 & 1 \\
\hline & Spare & 11 & -- \\
\hline & Asala Water & 11 & 3.5 \\
\hline & Post Office & 11 & 2.5 \\
\hline & Al Rabee & 11 & 0.25 \\
\hline \multirow{14}{*}{$\begin{array}{l}\text { Al Qadisyeh (Al- } \\
\text { a'meem) } \quad 33 \mathrm{KV}\end{array}$} & 18 Kilo & 11 & 18 \\
\hline & Al Makhazen & 11 & 2 \\
\hline & Al Neft & 11 & 3 \\
\hline & University & 11 & 2 \\
\hline & Al Laj'een (1) & 11 & 8 \\
\hline & Al Laj'een (2) & 11 & 35 \\
\hline & Tameem Generators Diesel 1 & 11 & 1 \\
\hline & Tameem Generators Diesel 2 & 11 & 1 \\
\hline & Al Ceramic & 11 & 2 \\
\hline & AL Sena'a & 11 & 4 \\
\hline & Al Qadisyeh & 11 & 5 \\
\hline & 30 Tamouz & 11 & 3 \\
\hline & Spare (1) & 11 & -- \\
\hline & Spare (2) & 11 & -- \\
\hline
\end{tabular}


Table 3: Length of the existing distribution network with the main and sub-stations and the number of transformers / continued

\begin{tabular}{cccc}
\hline Station Name & Feeder & Voltage KV & Length (km) \\
\hline & North Ramadi (1) & 33 & 5 \\
North Ramadi (2) & 33 & 5 \\
& Old Heit & 33 & destroyed \\
& Qadisyeh 12 & 33 & 3.5 \\
Qadisyeh 11 & 33 & 3.5 \\
Zujaj (1) & 33 & 0.5 \\
National Al Ramadi & Zujaj (2) & 33 & 0.5 \\
(AL Warrar) & Al Tharthar & 33 & 40 \\
132 KV & Al Sekak & 33 & destroyed \\
& Al Bofraj & 11 & 10 \\
Al Fater & 11 & 20 \\
& Al Ta'meem & 11 & 4 \\
& Maternity Hospital & 11 & 2 \\
Madinah 3 & 11 & 9 \\
& Madinah 6 & 11 & 35 \\
Zankurah & 11 & 10 \\
& Al Dawajen & 11 & 20 \\
& Tawi & 11 & 12 \\
& Albo Thyab & 11 & 3 \\
& Saylo (1) & 11 & 3 \\
& Saylo (2) & 11 &
\end{tabular}

*There are three Spare Feeders of $33 \mathrm{~K} . \mathrm{V}$

Table 4: Existing distribution network length with the main and sub-stations and the number of transformers [6

\begin{tabular}{cccc}
\hline Station Name & Feeder & Voltage KV & Length (km) \\
\hline & Al- khaldyeh & 33 & 22 \\
& Sadamyeh Al Tharthar & 33 & 30 \\
Al- Haq & 11 & 12 \\
East Al & Albo Ghanem & 11 & 3.5 \\
Ramadi & Al- Shurka & 11 & 4 \\
(Al Soufyeh) & Albo Mahel & 11 & 4 \\
132 KV & Albo Khalifah & 11 & 2.5 \\
& Al Shurtah & 11 & 15 \\
& Al - Yarmouk & 11 & 12 \\
& Sadet Sigaryeh & 11 & -- \\
& Albo Fahed & 11 & 7
\end{tabular}

* There are 13 Spare Feeders of 33 K.V and 5 Feeders of 11 K.V

Table 5: Type of electrical energy consumers and their numbers in the city of Al Ramadi [9]

\begin{tabular}{cc}
\hline Type of Consumption & Number of Consumers \\
\hline Domestic & 116321 \\
Commercial & 18362 \\
Industrial & 1035 \\
Agricultural & 6179 \\
Governmental & 2245 \\
TOTAL: & 144142 \\
\hline
\end{tabular}

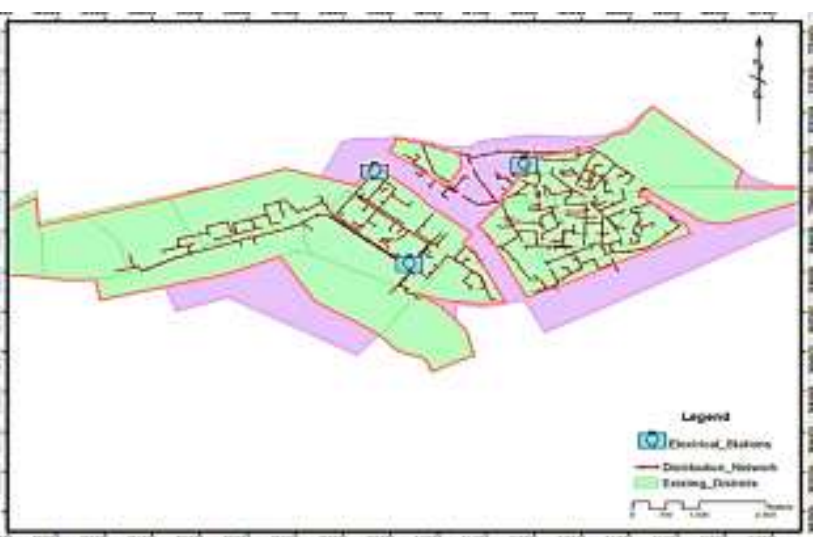

Figure 3: Map of Existing Electrical Distribution Network 


\subsection{Consumption}

In the current situation, and in the absence of any industrial or agricultural projects, the City of Al Ramadi, consumes about $200 \mathrm{MW}$, and the demand is expected to increase by $25-30 \%$ during the summer of 2018. [9] If we take into account, the population explosion experienced by all cities of Iraq, then this consumption is likely to grow more and more with time.

Because of the increasing demand for electricity by consumers, the infringing on networks by illegal connections increased, which increased the problems of the network's control and maintenance. This encroachment was observed in the agricultural sector due to connecting of water pumps, as well as in the residential sector to feed air conditioning. This makes the network, which is already non-sufficient, burdened by unexpected and unaccounted for loads.

\section{Current and Future Projects For Electricity Sector}

Figure 4 shows a map of the existing power stations as well as some of the stations under construction or proposed to improve the capacity of the existing power network as follows:

1) Al Haditha Diesel Station Project with a full production capacity of 10 x 23 Megawatts.

2) Al Anbar Steam Station Project (under construction) and currently stops at the stage of evaluating proposals that were submitted for the construction of the station. With a production capacity of 4 x300 Megawatts.

3) A Power Station Project belongs to the compound of petrochemical industries in Akashat / Al-Qa'em Region and Ministry of Industry with a full production capacity of 50 Megawatts.

4) Al Anbar Steam Station, which will operate on HFO fuel or crude oil or natural gas from Akkaz field, with an annual production capacity of 4 x125 Megawatts.

5) Qadisiya Station Project (33 KV), with a total production capacity of 30 Megawatts.

6) Fallujah Station Project (132 KV) with a total production capacity of 30 Megawatts.

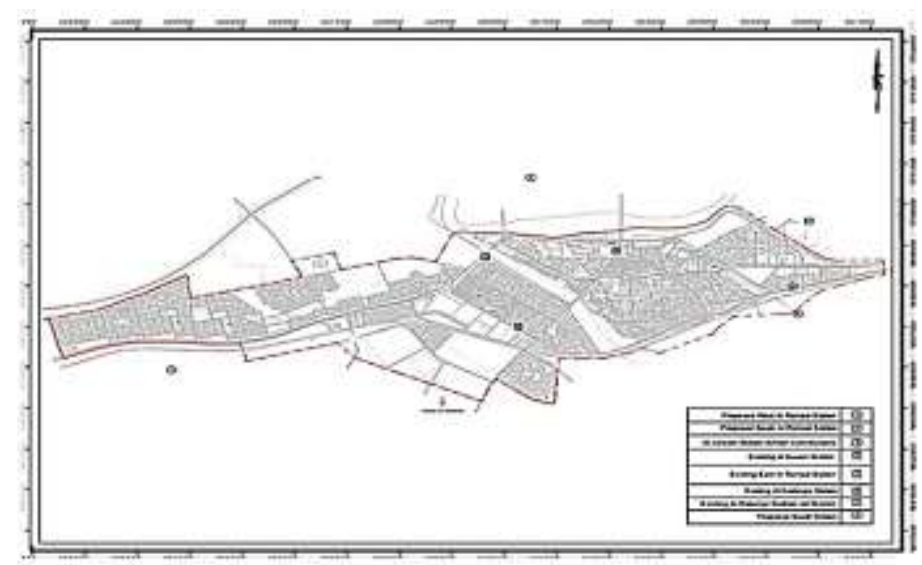

Figure 4: Map of Existing, Under Construction and Proposed Electric Stations

\section{Results and discussion tentative solutions for electricity sector}

One of the goals in geomatics was to take information and characteristics about the location of facilities and integrate them with other attribute databases Geomatics is a valuable framework for describing groups of map layers or themes that are all linked to a similar database or geographic area .and link relation databases for GIS use. The current electricity network in $\mathrm{Al}$ Anbar Governorate, in general, and in the City of Al Ramadi, in particular, is experiencing a significant deficit in providing citizens with necessary electricity services, as the output of Sad Al Haditha Station, which distributes electricity to all of Al Anbar Governorate is not sufficient to meet the demand of the City of Al Ramadi alone. Therefore, people resort using of private diesel generators in order to meet their needs. So, the required solutions should be developed to meet deficits and shortages of electricity through the construction of new generation stations. The following summarizes the main problems:

1) The existing network has been already old and deteriorated, and its condition deteriorated further as a result of the recent destruction of infrastructure in Al Ramadi and other cities of Iraq.

2) Increasing demands on energy in the residential and commercial areas of the city.

3) The lack of secondary transforming stations $(11 / 33 \mathrm{KV})$ in the city.

4) Inadequacy of existing infrastructure network, such as cables, towers, poles, and other system components.

5) Lack of spare parts, especially cables and transformers and circuit breakers.

6) Lack of materials needed to establish new networks and stations.

7) Inadequacy of specialized maintenance machines.

8) Inadequate maintenance centers.

The share of Al Anbar Governorate of electrical energy reaches about $4 \%$ of total available electrical energy and this proportion is very small compared with governorate needs. This greatly affects factory production in the city, where most of these factories stopped working, such as cement, glass and ceramics factories. In addition, it affects hospitals and health facilities where they need permanent electrical power. Therefore, a detailed study should be prepared; according to priorities, about the problem of generating electricity, and it should be coordinated with electrical projects' companies and the concerned 
ministries, as well as developing possible solutions and recommendations. Initial solutions for reducing this problem could be summarized as follows:

1) Completion of electrical station for high tension of $(400 \mathrm{KV})$ with the connected network between it and main transforming stations.

2) Establishment of transforming stations $(33 / 11 \mathrm{KV})$ and installing of new lines of $(33 \mathrm{KV})$, to feed the new stations.

3) Connecting electricity to neighborhoods and surrounding villages through the establishment of a new network of (11/0.4 $\mathrm{KV}$ ).

4) Improving services at the level of workers and machines and improving communications network that links maintenance centers to control centers.

5) Securing new maintenance centers equipped with all necessary safety equipment and improving the capacity of technical staff.

\section{Conclusion}

GIS can effectively manage data on electricity distribution as well as data identifying attributes such as location and electrical use. Its main function is an interactive map with databases that can be used to create maps to analyze the network. The digital interface allows for timely, accurate, and easy information acquisition, which is important for making quick and effective decisions. The power generation sector in Iraq, in general, and Al Anbar Governorate and Al Ramadi City, in particular, suffer from insufficient capacity compared to neighboring countries, and the whole country suffers from severe rationing and power shortages and disruptions. Rehabilitation and/or upgrading works are required for existing plants, and additional plants need to be constructed to meet future demands. The transmission and distribution systems in Al Ramadi require expansion and/or rehabilitation as necessary to accommodate load growth and offer better reliability. New high tension substations may need to be constructed to upgrade the level of electrical utility services in the region.

The present distribution systems in Al Ramadi are mostly overhead. Gradual conversion from overhead to underground systems, particularly at the $11 \mathrm{kV}$ level, is recommended, especially in the central part of the city. This will allow for higher system safety and reliability, and for a much aesthetically improved appearance.

This necessitated the construction of additional backup stations. Furthermore, prepared a future plan for stations that have to be constructed by the year 2020, in order to meet the anticipated demand growth during the planning period. Long-term plan for the Governorate of $\mathrm{Al}$ Anbar in order to cope with the increased demand for electrical energy.

\section{Acknowledgment}

I would like to express my thanks of gratitude to the Local power, authority Electricity Directorate of Al Anbar as well as the Ministry of Municipalities and Public Works opportunity to do this research on the topic (Assessment of Electricity Sector using Geomatics techniques: (Ramadi city as a case study).

Author contribution

All authors contributed equally to this work.

Funding

This research received no specific grant from any funding agency in the public, commercial, or not-for-profit sectors.

Data availability statement

The data that support the findings of this study are available on request from the corresponding author.

Conflicts of interest

The authors declare that there is no conflict of interest.

\section{References}

[1] M. A. Rob, Applications of Geographical Information Systems in Understanding Spatial Distribution of Asthma, Informing. Sci. J., 6(2003)4. http://dx.doi.org/10.28945/516

[2] R. L. Church \& T. A. Murray, Business Site Selection, Location Analysis, and GIS, Willy books, 2009.

[3] Haining, R.P., Designing spatial data analysis modules for GIS In A.S. Fotheringham and P. Rogerson, Spatial Analysis and GIS. London, Taylor and Francis, (1994)45-60. https://doi.org/10.1201/9781482272468

[4] Ministry of Construction and Housing Baghdad-Iraq / Public Housing Authority / Division of Studies - urban housing standards Notebook, 6, 2010.

[5] IEC and NEMA Standards for the characteristics of all equipment forming part of the work, 2020.

[6] Local power authority,Electricity Directorate of Al Anbar requirements and practices, 2018.

[7] Surya Santoso and H. Wayne Beaty, Standard Handbook for Electrical Engineers for power distribution, 17th ed, ,61-65, 2018.

[8] National Electric Code NCE NFPA 70, Power installations and grounding, 2010.

[9] Ministry of Municipalities and Public Works, Regional Context and Major Development issues- Ramadi City , 2010. 